\title{
PERANCANGAN SISTEM INFORMASI AKADEMIK PADA MADRASAH ALIYAH SMIP 1946 BANJARMASIN
}

\author{
Muhammad Rais Wathani'), Zaenuddin ${ }^{2)}$ \\ ${ }^{1}$ Fakultas Teknologi Informasi, Universitas Islam Kalimantan Banjarmasin \\ Email : raiswathani@gmail.com \\ ${ }^{2}$ Fakultas Teknologi Informasi, Universitas Islam Kalimantan Banjarmasin \\ Email : zaenuddin.uniska@gmail.com
}

\begin{abstract}
Abstrak
Banyak kendala dan kesulitan yang dihadapi guru dan pihak sekolah dalam permasalahan akademik, diantaranya sekolah memiliki siswa dan guru yang cukup banyak dan terus bertambah dari tahun ke tahun, akan tetapi hampir seluruh kegiatan yang bersifat administrasi masih dilakukan secara manual, walaupun sebagian sudah dalam bentuk worksheet. Tujuan dari penelitian ini adalah untuk mendesain dan merancang sebuah Sistem Informasi Akademik pada Madrasah Aliyah SMIP 1946 Banjarmasin, diharapkan dapat mempercepat proses pengolahan data guru, data siswa, data pelajaran dan data nilai serta meminimalis terjadinya kesalahan yang mungkin terjadi, sehingga dapat membantu memberikan informasi yang cepat, tepat dan akurat. Perancangan penelitian yang dilakukan adalah menggunakan pendekatan System Development Life Cycle (SDLC), yaitu tahapan-tahapan dalam membangun sesuah sistem informasi yang dilakukan oleh analis sistem dan programmer. Hasil dari penelitian ini adalah metode SDLC sangat cocok digunakan untuk membangun sistem informasi akademik, terbukti dengan terselesaikannya pembuatan sistem informasi ini dengan baik. Sistem ini dapat membuat laporan secara cepat dan efisien sesuai dengan data yang diinput. Sehingga diharapkan pihak-pihak yang memerlukan dapat memperoleh laporan dari setiap transaksi atau kegiatan yang ada tepat pada waktunya.
\end{abstract}

Keywords : Sistem Informasi, Akademik, Aliyah, SDLC, System Development Life Cycle

\section{PENDAHULUAN}

Madrasah Aliyah SMIP 1946 sebagai salah satu sekolah atau institusi pendidikan berbasis agama setara SMA yang pertama di Banjarmasin, tentu menginginkan terlaksananya kegiatan akademik yang baik dan lancar agar mampu menghasilkan lulusan yang unggul dan mampu bersaing dengan sekolah lainnya.

Madrasah Aliyah SMIP 1946 Banjarmasin memiliki siswa dan guru yang cukup banyak dan terus bertambah dari tahun ke tahun, akan tetapi hampir seluruh kegiatan yang bersifat administrasi masih dilakukan secara manual, hanya sebagian yang sudah dalam bentuk file worksheet. Seluruh data profil guru dan siswa masih tertulis secara manual dalam buku besar yang diarsipkan oleh bagian akademik, absensi harian masih dilakukan manual yang pada tiap akhir semester akan direkap oleh guru wali kelas masing-masing, guru mata pelajaran membuat rekap nilai siswa pada lembar khusus penilaian yang kemudian diserahkan kepada guru wali kelas, selain itu pelanggaran dan penghargaan yang diberikan guru kepada siswa dicatat dalam buku khusus, berdasarkan perhitungan poin tertentu.

Banyak kesulitan yang dihadapi apabila masih menggunakan cara-cara manual, diantaranya adalah sulitnya menyajikan informasi apabila diperlukan sewaktu-waktu, sulit dalam mengolah data menjadi bentuk tertentu sesuai keinginan, kesulitan dalam pencarian data tertentu dalam buku besar karena tidak ada filter dalam pecarian data, terhambatnya proses kerja disebabkan adanya kesalahan dalam proses pencatatan atau pengelolaan data berskala besar. Terkadang orang tua siswa menginginkan data tentang perkembangan kegiatan belajar anaknya, dan para guru tidak mampu memberikannya, karena hasil perkembangan kegiatan belajar anak hanya diberikan saat pembagian raport diakhir semester. 
Banyak lagi kendala dan kesulitan lainnya yang dihadapi guru dan pihak sekolah dalam permasalahan akademik. Sehingga diantara sekian banyak kegiatan yang dilakukan, sangat menguras waktu, tenaga dan pikiran, karena sebagian besar masih dilakukan secara manual. Data akademik yang semakin bertambah banyak akan sangat merepotkan jika masih terus diolah secara manual.

Dengan adanya kendala yang dihadapi di atas, Madrasah Aliyah SMIP 1946 Banjarmasin memerlukan suatu sistem yang mampu mengatasi atau setidaknya mengurangi permasalahan tersebut.

Sistem informasi akademik adalah perangkat lunak yang digunakan untuk menyajikan informasi dan menata administrasi yang berhubungan dengan kegiatan akademik. Dengan penggunaan perangkat lunak ini diharapkan kegiatan administrasi akademik dapat dikelola dengan baik dan informasi yang diperlukan dapat diperoleh dengan mudah dan cepat. Hal inilah yang melatar belakangi penelitian ini, sehingga tertarik mengambil judul "Perancangan Sistem Informasi Akademik pada Madrasah Aliyah SMIP 1946 Banjarmasin".

Tujuan dari pelaksanaan penelitian ini adalah untuk menganalisa, mendesain dan merancang suatu sistem informasi akademik di Madrasah Aliyah SMIP 1946 Banjarmasin, sehingga diharapkan dapat mempercepat proses pengolahan data guru, data siswa, data pelajaran dan data nilai serta meminimalis terjadinya kesalahan yang mungkin terjadi.

Jeffri Prayitno Bangkit Saputra, pernah melakukan penelitian pada bagian akademik siswa di SMP Negeri 1 Pengadegan Kabupaten Purbalingga, khususnya pada proses pengolahan nilai, dengan membuat sebuah sistem informasi akademik untuk sekolah SMP. Metode yang digunakan dalam merancang dan membangun sistem adalah metode berorientasi objek. Sistem ini dapat mengatasi masalah yang sebelumnya ada yaitu dalam pengolahan data-data penilaian serta dapat membantu petugas dalam membuat laporan yang dibutuhkan. Wina Widiati juga melakukan penelitian yang sama dengan membuat sistem informasi akademik dengan target SMA Widya Nusantara Bekasi, metode yang digunakan adalah SDLC (System Development Life Cycle). Hasil dari penelitian ini adalah berupa sistem informasi akademik yang dapat membantu mengatasi permasalahan yang selama ini dihadapi sehingga dapat mempermudah kegiatan atau aktifitas kerja yang memerlukan kecepatan dan ketepatan informasi.

\section{METODE PENELITIAN}

Perancangan penelitian yang dilakukan adalah menggunakan pendekatan System Development Life Cycle (SDLC) atau siklus hidup pengembangan sistem, yaitu suatu proses pembuatan dan pengubahan sistem serta model dan motodologi yang digunakan untuk mengembangkan sistem tersebut. SDLC bisa pula diartikan sebagai tahapan-tahapan dalam membangun sesuah sistem informasi yang dilakukan oleh analis sistem dan programmer.

Tahapan-tahapan dalam membangun sistem informasi diawali dengan Analisis Sistem, tahapan ini dilakukan karena adanya permintaan terhadap sistem baru atau pengembangan dari sistem yang sudah ada. Analisis sistem ini terbagi atas dua kegiatan, studi kelayakan dan analisis kebutuhan sistem. Kemudian dilanjutkan dengan Desain/Perancangan Sistem yang meliputi perancangan konseptual dan perancangan fisik. Setelah itu dilanjutkan dengan Pengujian Sistem dan diakhiri dengan Implementasi dan pemeliharaan sistem.

Langkah/tahapan tersebut dapat dilihat sebagaimana yang ditunjukkan dalam bentuk skema di bawah ini :



Gambar 1. Perancangan Penelitian

\section{HASIL DAN PEMBAHASAN Analisis Sistem}

Pada tahap ini, analis sistem atau programmer memerlukan komunikasi yang baik dengan tempat penelitian dalam rangka pembuatan atau pengembangan sistem informasi, yang bertujuan 
untuk memahami perangkat lunak yang diharapkan oleh pengguna/user serta batasan-batasan dari perangkat lunak tersebut. Pada tahap ini terbagi atas 2 (dua) bagian, yaitu analisis sistem yang berjalan dan analisis kebutuhan sistem.

Pada tahap analisis sistem yang berjalan, dicari informasi tentang bagaimana sistem yang berjalan saat ini, apakah berjalan secara manual, konvensional atau telah digunakan suatu sistem tetapi masih dirasa kurang sehingga perlu adanya pengembangan untuk mengatasi berbagai masalah, tahap ini dilakukan melalui wawancara, diskusi atau survei langsung ke lapangan. Hasil dari analisis sistem yang berjalan adalah didapatkannya suatu solusi untuk pengembangan dari sistem yang lama. Sedangkan tahap analisis kebutuhan sistem, merupakan tahap lanjutan dari tahap analisis sistem yang berjalan, dimana informasi yang telah didapat kemudian dianalisis untuk mendapatkan data yang dibutuhkan oleh pengguna sehingga menghasilkan spesifikasi kebutuhan, yaitu perincian mengenai apa saja yang dibutuhkan dalam pengembangan sistem dan membuat perencanaan yang berkaitan dengan proyek sistem.

\section{Analisis sistem yang berjalan}

Sistem dan prosedur akademik yang berjalan saat ini di Madrasah Aliyah SMIP 1946 Banjarmasin masih menggunakan cara manual dan semi komputerisasi, yaitu dengan menyimpan data akademik di dalam buku besar dan sebagian disimpan di komputer menggunakan software Microsoft Word dan Excel, sehingga bisa disimpulkan bahwa Sekolah tersebut belum menggunakan sistem informasi akademik.

\section{Analisis kebutuhan sistem}

Adapun kebutuhan sistem yang digunakan dalam pembuatan atau pengembangan sistem informasi yang akan dibuat adalah sebagai berikut:

Untuk Perangkat Keras (Hardware) yang digunakan, minimal menggunakan PC desktop, PC Mini, PC All in one atau komputer jinjing (laptop) dengan spesifikasi minimal Processor Intel celeron, Harddisk dengan space kosong sebesar 50MB, Memory DDR3 minimal 1GB, LCD/LED monitor minimal 10inch. Sedangkan untuk Perangkat Lunak (Software) yang digunakan minimal Sistem Operasi Windows $\mathrm{XP}$ ke atas.

\section{Desain / Perancangan Sistem}

Tahap ini maksudnya adalah membuat desain aliran kerja manajemen dan desain pemrograman yang diperlukan untuk pembuatan atau pengembangan sistem informasi, seperti pembuatan diagram konteks, desain database, rancangan antarmuka masukan sistem dan rancangan antarmuka luaran sistem

\section{Diagram Konteks}

Diagram konteks merupakan diagram yang terdiri dari suatu proses dan menggambarkan ruang lingkup suatu system, diagram ini menggambarkan seluruh input ke dalam sistem atau output dari sistem yang memberi gambaran tentang keseluruhan sistem.

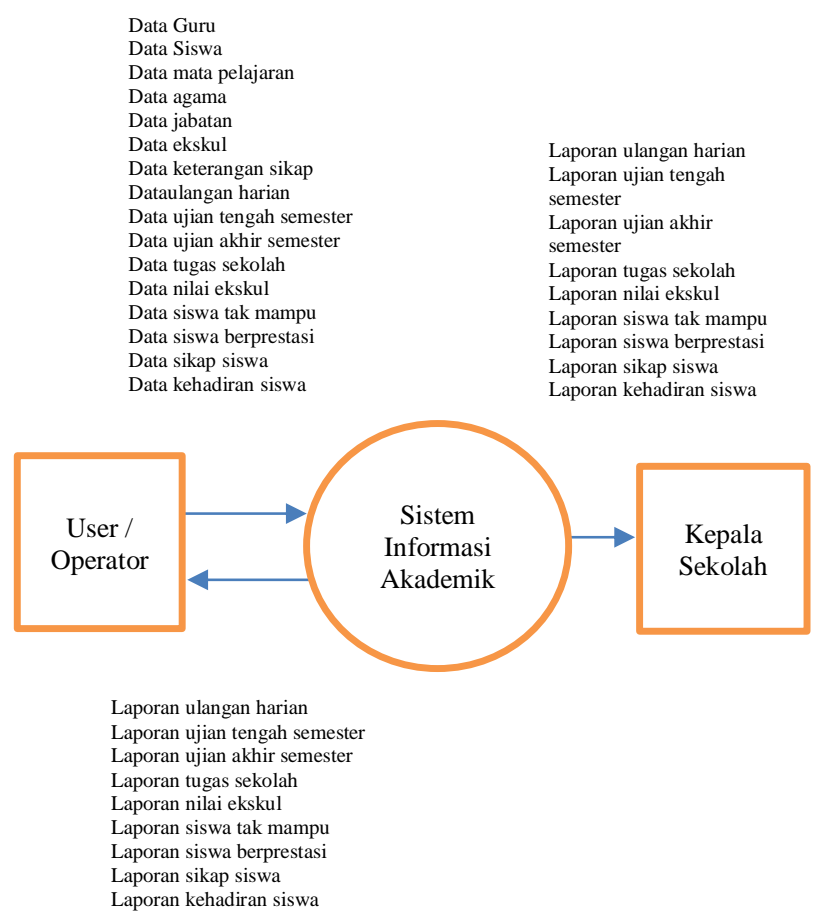

Gambar 2. Diagram Konteks 


\section{Kamus Data}

Terdapat 15 tabel yang digunakan dalam menunjang pembuatan sistem informasi akademik ini, dintaranya adalah : Tabel Agama yang diberi nama tb_agama, Tabel Ekstrakurikuler yang diberi nama tb_ekstra, Tabel Guru yang diberi nama tb_guru, Tabel Jabatan yang diberi nama tb_jabatan, Tabel Kehadiran yang diberi nama tb_kehadiran, Tabel Keterangan Sikap yang diberi nama tb_ket_sikap, Tabel Nilai yang diberi nama tb_nilai, Tabel Nilai Detail yang diberi nama tb_nilai_detail, Tabel Nilai Ekstrakurikuler yang diberi nama tb_nilai_ekskul, Tabel Pelajaran yang diberi nama tb_pelajaran, Tabel Prestasi yang diberi nama tb_prestasi, Tabel Sikap yang diberi nama tb_sikap, Tabel Sikap Detail yang diberi nama tb_sikap_detail, Tabel Siswa yang diberi nama tb_siswa, dan Tabel Siswa Tak Mampu yang diberi nama tb_tak_mampu.

\section{Antarmuka Masukan Sistem}

Antarmuka masukan sistem merupakan hasil realisasi dari rancangan antarmuka masukan sistem yang telah dirancang di awal. Antarmuka ini berupa menu utama dan formform masukan input dari data master dan data proses.

Antarmuka pertama adalah halaman / form login yang bertujuan untuk keamanan sistem, agar pengguna yang dapat menggunakan sistem adalah pengguna yang memang telah terdaftar. Untuk dapat masuk sistem dengan cara memasukkan username dan password kemudian login. Untuk pembuatan user name baru beserta hak aksesnya, bisa masuk ke dalam menu utility kemudian pilih hak akses.

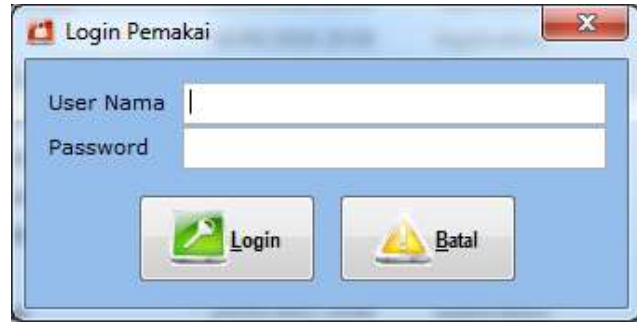

Gambar 3. Form Login Pemakai/ User
Setelah berhasil login dengan username dan password yang benar, maka akan tampil menu utama seperti gambar di bawah ini.

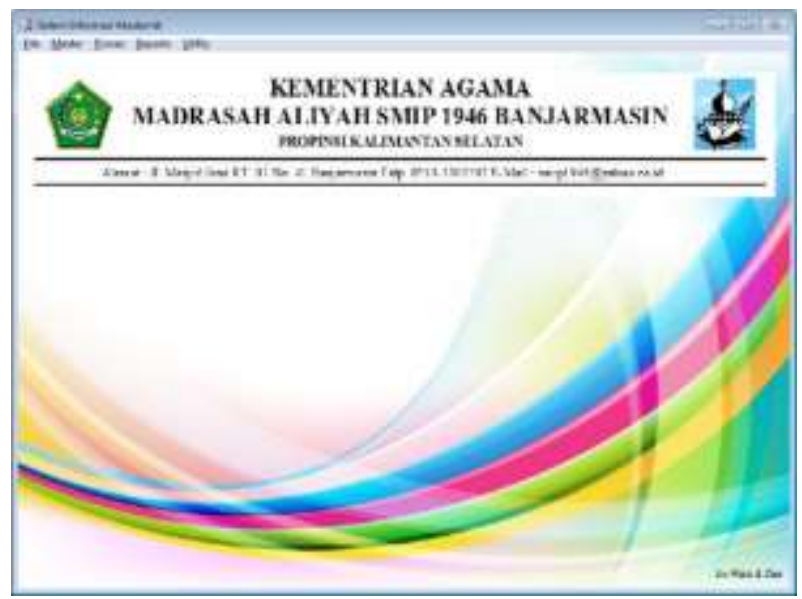

Gambar 4. Form Menu Utama

Terdapat beberapa menu diantaranya menu File yang terdiri atas logout dan exit; menu Master terdiri atas mata pelajaran, agama, jabatan, guru, siswa, ekskul dan keterangan sikap; menu Proses terdiri atas ulangan harian, ujian tengah semester, ujian akhir semester, tugas sekolah, nilai ekskul, siswa tak mampu, siswa berprestasi, sikap siswa dan kehadiran siswa; menu Reports terdiri atas rekap ulangan harian, rekap ujian tengah semester, rekap ujian akhir semester, rekap tugas sekolah, rekap nilai ekskul, rekap siswa tak mampu, rekap siswa berprestasi, rekap sikap siswa dan rekap kehadiran siswa. Adapun menu Utility terdiri atas backup, restore dan hak akses.

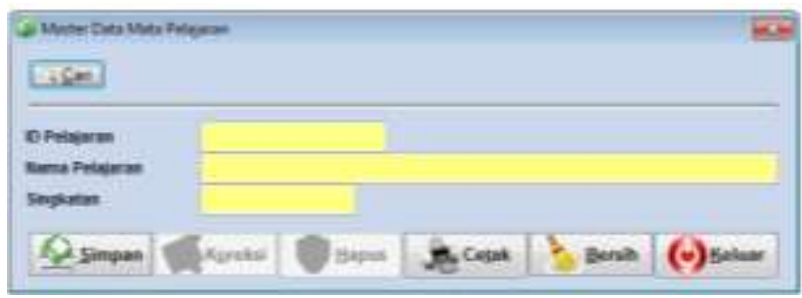

Gambar 5. Form Master Data Mata Pelajaran

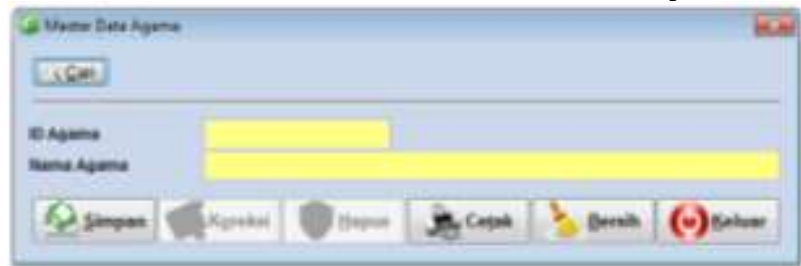

Gambar 6. Form Master Data Agama 


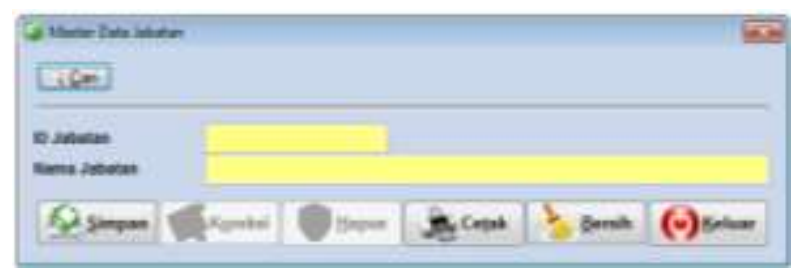

Gambar 7. Form Master Data Jabatan



Gambar 8. Form Master Data Guru

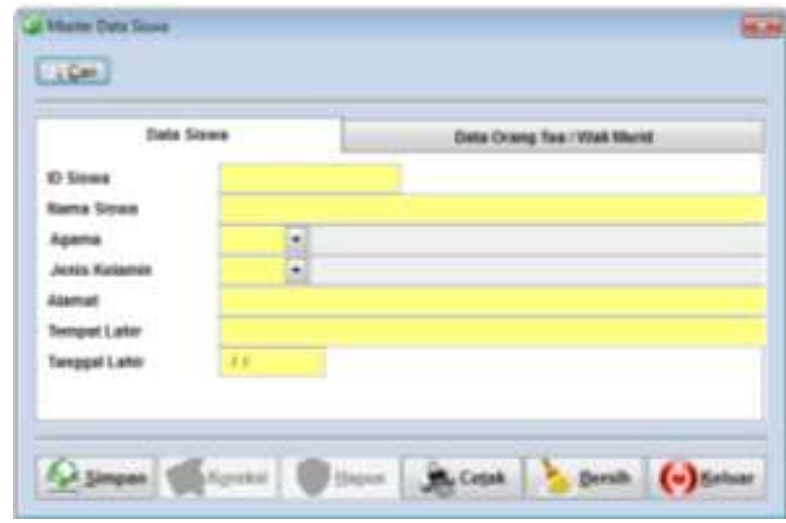

Gambar 9. Form Master Data Siswa dan Orang Tua/Wali Siswa



Gambar 10. Form Data Ulangan Harian

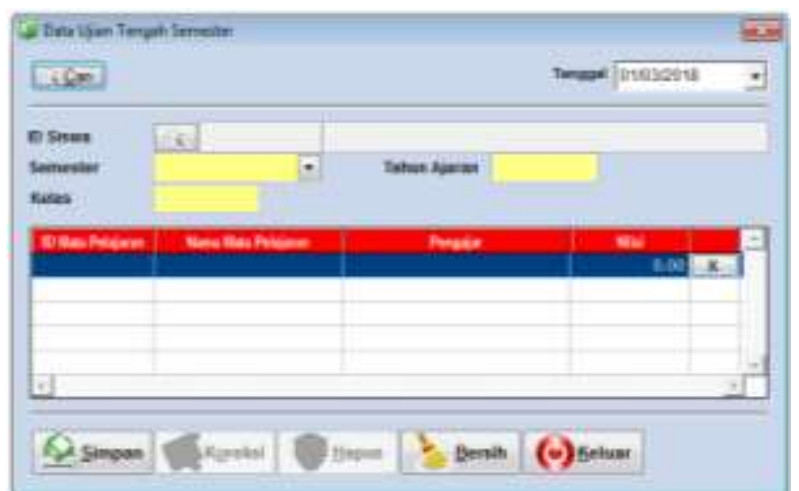

Gambar 11. Form Data Ujian Tengah Semester

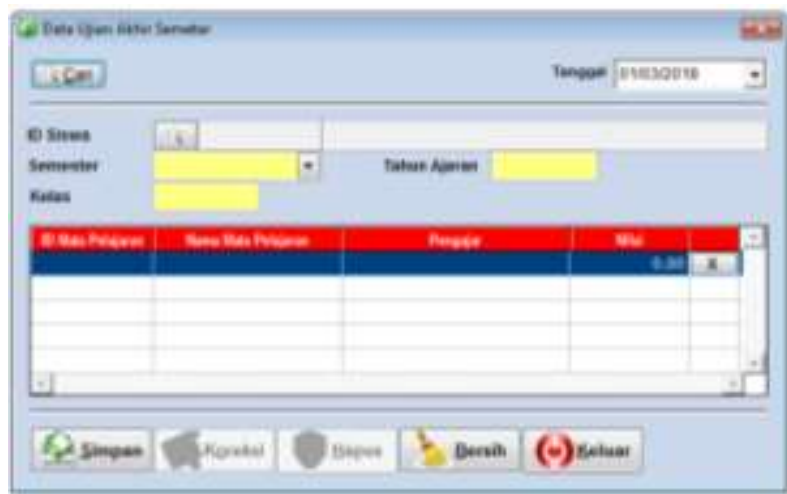

Gambar 12. Form Data Ujian Akhir Semester

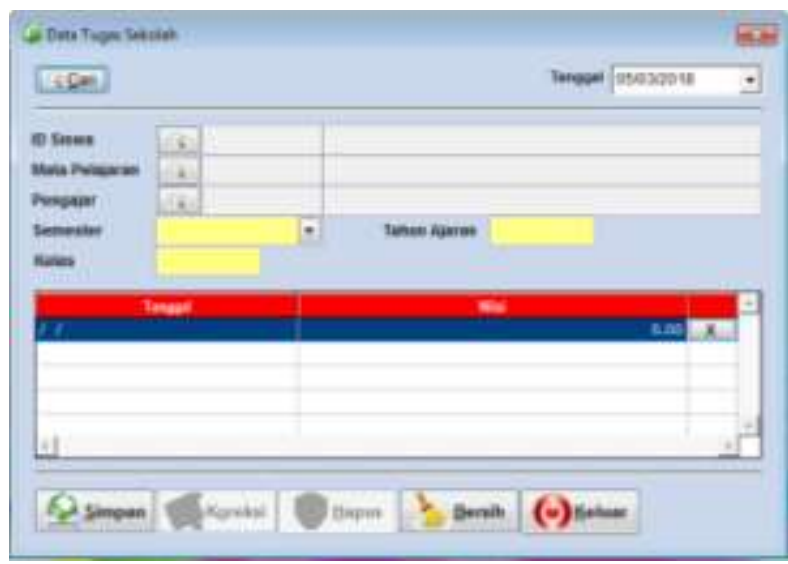

Gambar 13. Form Data Tugas Sekolah

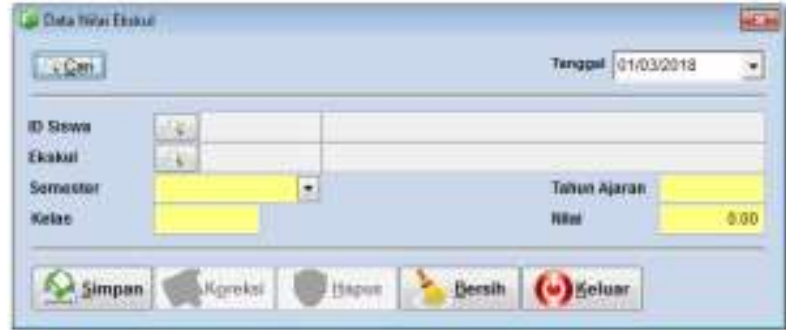

Gambar 14. Form Data Nilai Ekskul

Jurnal Ilmiah”Technologia” 




Gambar 15. Form Siswa tak Mampu



Gambar 16. Form Siswa Berprestasi

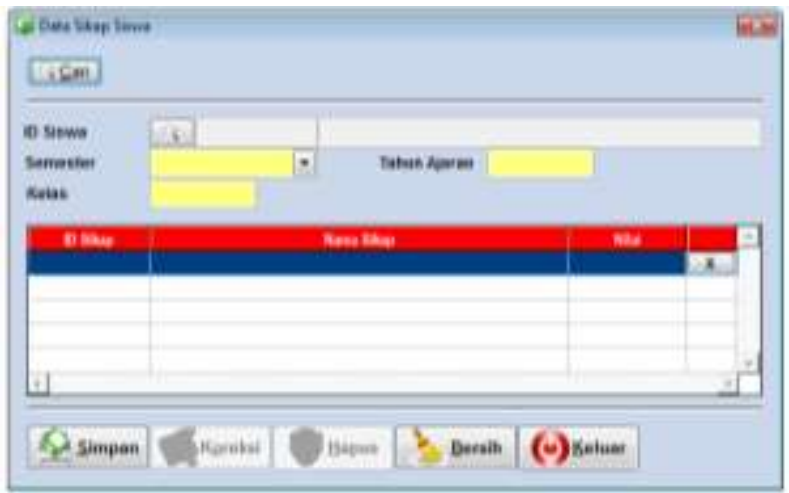

Gambar 17. Form Data Sikap Siswa

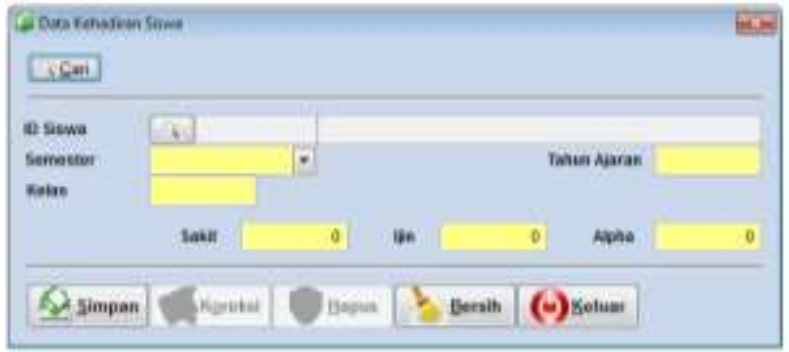

Gambar 18. Form Data Kehadiran Siswa



Gambar 19. Menu Utility untuk Backup Data



Gambar 20. Menu Utility untuk Restore Data

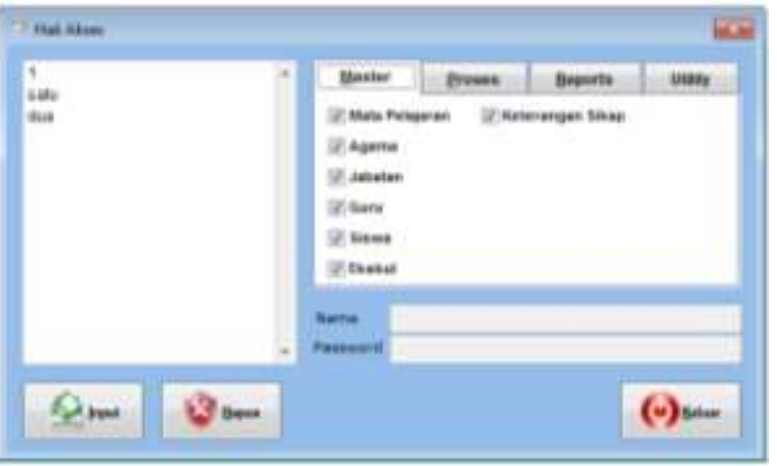

Gambar 21. Menu Utility untuk Hak Akses

\section{Antarmuka Luaran Sistem}

Antarmuka luaran sistem merupakan hasil realisasi dari rancangan antarmuka luaran sistem yang telah dirancang di awal. Antarmuka ini berupa laporan atau hasil rekap dari data master dan data proses, antarmuka ini terdiri atas beberapa pilihan filter tertentu sesuai pilihan.

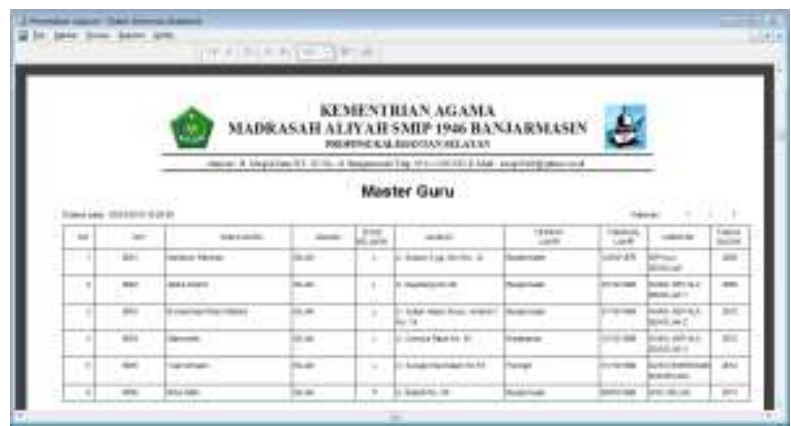

Gambar 22. Laporan Data Guru 




Gambar 23. Laporan Data Siswa

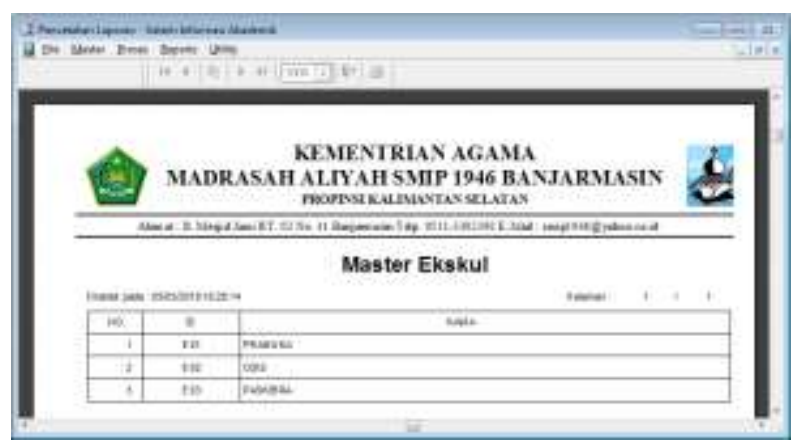

Gambar 24. Laporan Data Ekskul



Gambar 25. Laporan Data Keterangan Sikap

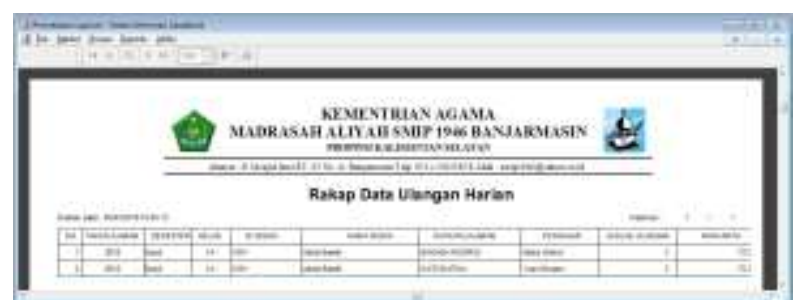

Gambar 26. Laporan Data Ulangan Harian

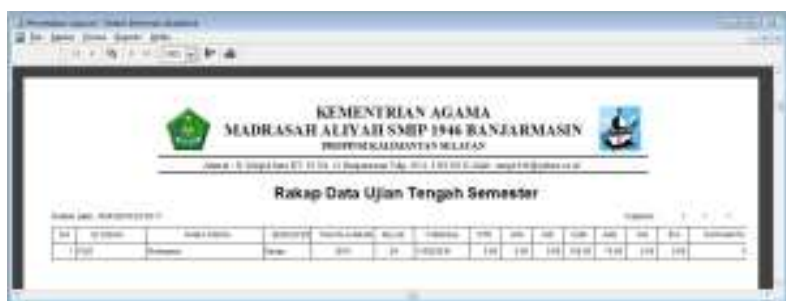

Gambar 27. Laporan Data Ujian Tengah Semester



Gambar 28. Laporan Data Ujian Akhir Semester

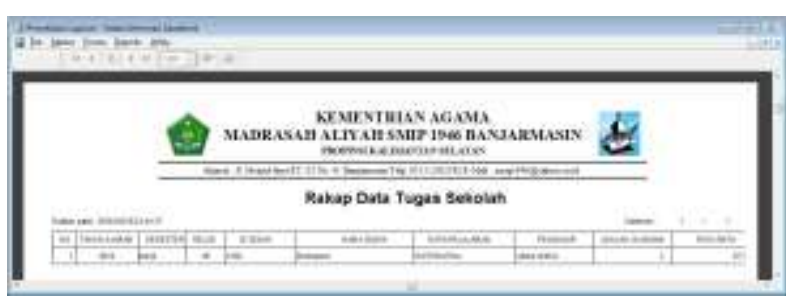

Gambar 29. Laporan Data Tugas Sekolah

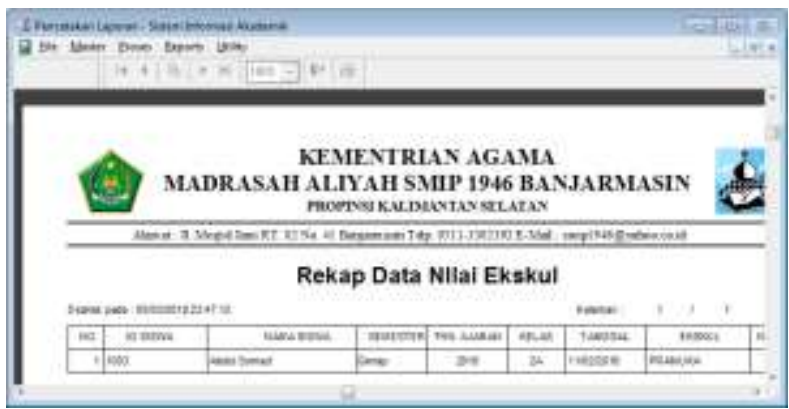

Gambar 30. Laporan Data Nilai Ekskul

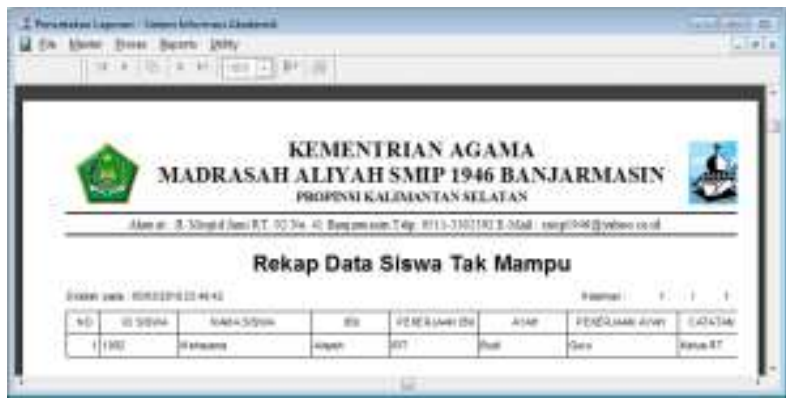

Gambar 31. Laporan Data Siswa tak Mampu 


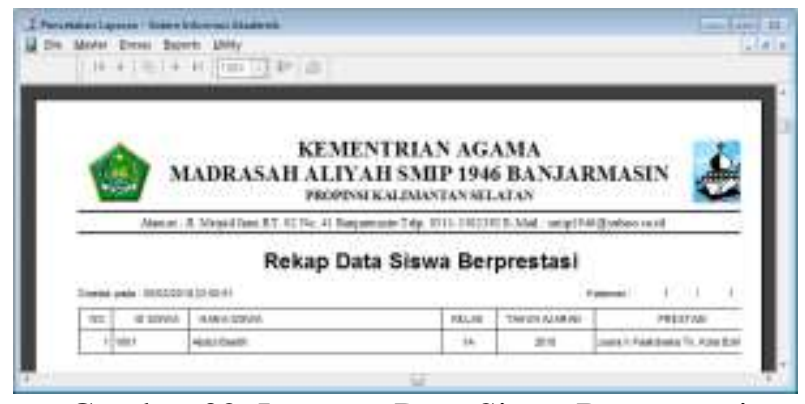

Gambar 32. Laporan Data Siswa Berprestasi

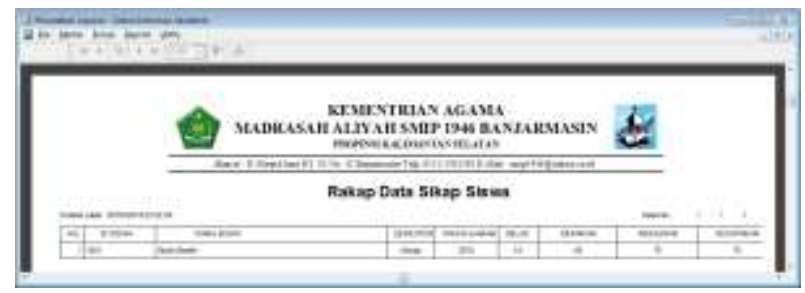

Gambar 33. Laporan Data Sikap Siswa

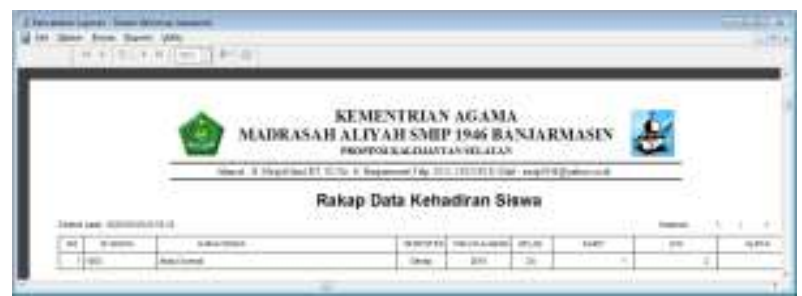

Gambar 34. Laporan Data Kehadiran Siswa

\section{KESIMPULAN}

\section{Kesimpulan}

1. Metode System Development Life Cycle (SDLC) atau siklus hidup pengembangan sistem, sangat cocok untuk membangun sistem informasi akademik ini, terbukti dengan terselesaikannya pembuatan sistem informasi ini dengan baik.

2. Sistem informasi akademik yang dibuat dapat membuat laporan secara cepat dan efisien sesuai dengan data yang diinput. Sehingga diharapkan pihak-pihak yang memerlukan dapat memperoleh laporan dari setiap transaksi atau kegiatan yang ada tepat pada waktunya.

\section{Saran}

1. Sistem informasi yang dibuat masih berupa aplikasi berbasis dekstop, diharapkan adanya pengembangan ke arah web sehingga lebih fleksibel dan mengatasi keterbatasan waktu dan tempat.

Jurnal Ilmiah"Technologia"
2. Perlu pengembangan ke arah yang lebih luas agar sistem informasi akademik ini juga dapat digunakan untuk semua sekolah, mulai dari tingkatan sekolah yang paling rendah hingga yang paling tinggi.

\section{DAFTAR PUSTAKA}

Indrayani, Etin. 2011. Pengelolaan Sistem Informasi Akademik Perguruan Tinggi Berbasis Teknologi Informasi dan Komunikasi (TIK). ISSN: 1412-565X. Bandung: Jurnal Penelitian Pendidikan Vol. 12, No. 1 April 2011: 51-67.

Jeffri Prayitno Bangkit Saputra. 2014. Sistem Informasi Akademik Dengan Metode Berorientasi Objek Pada Smp Negeri 1 Pengadegan Kabupaten Purbalingga. Sekolah Tinggi Manajemen Informatika Dan Komputer Amikom, Purwokerto

Jogiyanto, H.M. 2003. Sistem Teknologi Informasi. Penerbit Andi. Yogyakarta.

Kadir, Abdul. 2002. Pengenalan Sistem Informasi. Penerbit Andi. Yogyakarta.

Kadir, Abdul dan CH. Triwahyuni, Terra. 2003. Pengenalan Teknologi Informasi. Penerbit Andi. Yogyakarta.

Kristianto, Andi. 2008. Perancangan Sistem Informasi dan Aplikasinya. Gava Media. Yogyakarta.

Ladjamudin bin Al-Bahra. 2005. Analisis dan Desain Sistem Informasi. Edisi Pertama. Penerbit Graha Ilmu. Yogyakarta.

Saputra, Agus. 2012. Sistem Informasi Nilai Akademik Untuk Panduan Skripsi. Elex Media Komputindo. Jakarta.

Sutabri, Tata. 2012. Analisis Sistem Informasi. Penerbit Andi. Yogyakarta.

Tantra, Rudi. 2012. Managemen Proyek Sistem Informasi. Penerbit Andi. Yogyakarta.

Widiati, Wina. 2014. Sistem Informasi Akademik Pada Sekolah Menengah Atas Widya Nusantara Bekasi. AMIK BSI Jakarta. Jurnal Swabumi. Vol. I No. 1, September 2014. 
Yantu, Irwan. 2008. Penerapan Sistem Informasi Dalam Manajemen Sekolah. ISSN: 1693-9034. Gorontalo: Jurnal INOVASI Vol. 5, No. 3 September 2008: 136-146. 